\title{
Fremtidens Undervisningsmiljøer
}

\section{Lillian Buus}

E-læringskonsulent og PhD studerende

AAU IT Services, Aalborg Universitet.

\section{Uwe Wollin}

Chefkonsulent

ITMEDIA, Københavns Universitet.
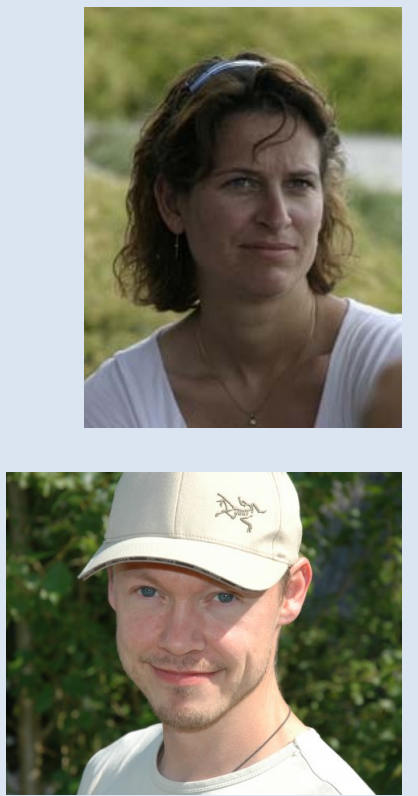

Dette temanummer er det første af LOM tidsskriftets temanumre, der har haft en kontinuerlig udgivelse. Det har betydet, at artiklerne er blevet udgivet i den rækkefølge med hvilken de har været klar til udgivelse. 


\section{Introduktion til "Fremtidens Undervisningsmiljøer"}

Som oplægget til dette temanummer af LOM også indikerede, så sætter vi fokus på fremtidens undervisningsmiljøer på universiteter og UCer. Fremtidens undervisningsmiljøer har mange facetter, hvilket samlingen af artikler også illustrerer. "Fremtidens Undervisningsmiljø" handler om eksisterende erfaringer med undervisning, som peger på potentialer, udfordringer, konkrete overvejelser og fremtidig anvendelse generelt $\mathrm{i}$ undervisningen i forhold til skabelsen af et decideret undervisningsmiljø. Når vi taler om fremtidens undervisningsmiljøer, så er denne ofte forbundet med en teknologisk opfattelse, f.eks. omkring brug af digitale medier i undervisningen, og hvordan disse er tænkt sammen med de fysiske rammer for undervisningen. Det bærer dette nummer af LOM også præg af.

Dette temanummer af LOM kan opdeles i 3 temaer; "Teknologisk understøttet praksis undervisning", "Undervisning via videostreaming"og "Online læringsmiljøer". I det efterfølgende har vi prøvet at give et overblik over de forskellige vinkler artiklerne har ind i disse forskellige temaer og tidsskriftets overordnede tema.

Tema 1: Teknologisk understøttet praksis undervisning

"Teknologisk understøttet praksis undervisning" er en mulighed der vinder frem som en undervisningsform der kan give studerende en større praksis erfaring $i$ en virtuel eller simuleret verden. I de to artikler der berører disse emner er en af de pointer som forfatterne trækker frem at især den didaktiske ramme for den teknologistøttende undervisning er vigtig at have et fokus på i tilrettelæggelsen.

* "Teknologistøttet simulationsundervisning - som translokation for teoretisk viden og praktisk handlen" af Nortvig og Eriksen Gennem denne artikel reflekterer forfatterne over hvordan den teoretiske viden og praktiske udførelse kan sammenkobles ved brug af simulationsundervisning, hvor teknologien skaber nogle muligheder for at gøre simulationerne så virkelighedsnære som muligt. Samtidig giver teknologistøttet simulationsundervisning hvor praksis er i fokus muligheden for at "pause virkeligheden" og få den teoretiske vinkel med ind over den simulerede praksis. Et interessant aspekt er at de studerende ser simulationsundervisning som en mulighed for at nedbryde kompleksiteten på studiets praksis undervisning i mindre dele, som over tid dog skaber den helhedsforståelse, de skal bruge, når de er færdiguddannede. Forfatterne konkluderer at anvendelsen af teknologi i forbindelse med simulationsundervisning bidrager til udvikling af de studerendes kompetencer, skaber en autistisk ramme for praksis samt er medvirkende til at skabe sammenhæng mellem teori og praksis. Der er dog stadig muligheder for den videre didaktiske udvikling af simulationsundervisning.

* "Online Farmakologi i et virtuelt laboratorium" af Dahl, Hedegaard og 
Musaeus

I denne artikel diskuteres potentialerne omkring det virtuelle laboratorium overfor det klassiske laboratorium indenfor rammen af bl.a. Bourdieus begreber habitus og hexis. Forfatterne tager udgangspunkt $i$ tre argumenter (praktisk, ideologisk og troværdighed) for hvorfor undervisning i et virtuelt laboratorium kan være et nødvendigt alternativ til den traditionelle laboratorie undervisningsform. Via en gennemgang af en case belyses disse argumenter ud fra styrker og svagheder ved de to undervisnings tilgange (virtuelt vs. klassisk). Artiklens forfattere konkluderer at især den didaktiske ramme for undervisningen er et vigtigt parameter for at læringspotentialet bliver en succes, og det gør sig gældende også i forhold til den måde hvorpå den virtuelle tilgang introduceres. Generelt er processen omkring den didaktiske implementering både tids- og ressourcekrævende vurderer forfatterne.

Tema 2: Undervisning via videostreaming

Et af de temaer der er kommet flest artikler omkring til dette LOM nummer omhandler "undervisning via videostreaming". Der er forskellige initiativer i gang, hvor det bl.a. drejer sig om at skabe fleksibilitet for de studerende i undervisningen ved brug af live transmission af undervisningen, samtidig med at logistik også spiller ind. Artiklerne rummer både muligheder i forhold til at skabe sammenhæng i undervisningen med forskellige lokaliteter; skabe mulighed for at studerende kan kombinere traditionel undervisning og online undervisning samt tilgodese brugere med særlige behov, som måske ikke vil have muligheden for at deltage i undervisningen på anden vis.

* "Live videotransmitteret undervisning - erfaringer og metodiske principper fra bioanalytikkeruddannelsen, VIA University College" af Ørngreen, Levinsen, Jelsbak, Møller og Bendsen

Artiklen præsenterer et aktionsforskningsprojekt baseret på et samarbejde mellem Professionshøjskolen VIA i Århus og Aalborg Universitet. Gennem artiklen præsenteres de udfordringer og potentialer som har vist sig $i$ projektet med etableringen af et kombi-hold, hvor traditionel undervisning kombineres med live-transmitteret undervisning. Projektets udfordringer og potentialer præsenteres og diskuteres i forhold til den studieaktivitetsmodel som Professionshøjskolernes Rektorkollegium har udviklet. I artiklen konkluderes det at netop den form for tilrettelæggelse af undervisningen betyder at forskellige behov dækkes i forhold til de studerende, samtidig har andre studerende ytret ønske om samme fleksibiliet i deres undervisningstilrettelæggelse, men det er forskernes vurdering af det vil kræve en gennemgribende re-didaktisering inden det kan effektueres i hele organisationen.

* "Global Classroom - videokonference i undervisning" af Nielsen 
På VUC Storstrøm inddrager undervisere videokonference i undervisningen ud fra to tilrettelæggelsesformer; Parallelundervisning og Global Classroom. Udgangspunktet herfor er at kunne binde afdelinger sammen på tværs, etablere hold der er rentable samt tilbyde undervisning til studerende som måske ikke ellers ville have muligheden for at modtage undervisning. Artiklen beskriver nogle af de erfaringer der er blevet gjort $i$ forhold til at indføre og gennemføre denne form for undervisning. Der er fokus på de overvejelser der bør ske når en sådan beslutning tages, samt de udfordringer som også følger med både teknisk, pædagogisk og organisatorisk. Artiklen beskriver også nogle af de positive aspekter der følger med i forhold til fleksibilitet, muligheden for at tilgodese brugere med særlige behov og ikke mindst udbyttet af de ny samarbejdsformer et sådan projekt etablerer. En central pointe $i$ artiklen er at det er vigtigt at der er tid nok til forberedelse af underviserne og deres undervisningspraksis i en ny kontekst, samt tid nok til også at få de tekniske detaljer på plads inden undervisningsformen indføres i undervisningen og så er det selvfølgelig vigtigt at de studerende også bliver orienteret om mulighederne.

* "Videomedieret parallelundervisning - som rum for læring ved Almen Voksenuddannelse i udkantsområder" af Andreasen og Rasmussen I artiklen præsenterer forfatterne resultater fra et følgeforskningsprojekt på VUC, hvor der er blevet undervist på flere lokationer samtidig og understøttet af video-streaming, hvilket $i$ artiklen bliver kaldet "parallelundervisning". Forfatterne præsenterer forskellige former for indretninger af rum, der understøtter forskellige former for læringsaktiviteter, men et aspekt er at især den ordinære klasseundervisning skaber en tryghed for netop den brugergruppe som er karakteristisk for kursister på Almen Voksenuddannelses (AVU) området, hvilket gør udfordringen med at køre parallelundervisning svær.

Konklusionen er at den form for undervisning som er afprøvet $i$ forløbet der beskrives i artiklen stiller høje krav til undervisningens tilrettelæggelse og kursisterne. Samtidig er der også nogle muligheder for at nå udkantsområder hvor der potentielt ikke er mulighed for at oprette hold pga. for få kursister. Det vil dog kræve nytænkning af undervisningen i AVU regi på flere områder så som indretning (lokaler), kollaborations muligheder, brugervenlig teknologi og de didaktiske overvejelser.

* "Potentialer og problematikker ved livestreaming og fastholdelse af undervisning" af Løkkegaard og Ryberg

Artiklen baserer sig på et eksperiment foretaget på Aalborg Universitet $i$ forhold til at livestreame undervisning til flere lokaler. Grundlaget for eksperimentet var dobbelt; 1) at der pga. stort optag af studerende dermed blev mangel på plads til at have alle studerende samlet og 2) muligheden for at eksperimentere med nye og anderledes måder at tilbyde undervisning på. Gennem analyse af interview, spørgeskemaer og observation belyser artiklens forfattere to temaer, som de har fundet 
gennemgående; kontrol og kontakt. Det interessante er at der i artiklen også berøres emner som fleksibiliet, muligheden for gentagelse og selvevaluering ved at fastholde undervisningen, men også barrierer eller reservationer ved netop mulighederne for at kunne gense forelæsningerne.

\section{Tema 3: Online læringsmiljøer}

Det tredje tema ligger indenfor en dialog omkring "online læringsmiljøer" og de læringsrum som kommer i spil når vi taler uddannelse og læring. Artiklerne kommer bl.a. omkring perspektiver indenfor både de asynkron og synkrone læringsmiljøer $i$ forhold til deres muligheder og begrænsninger. I to af artiklerne fremhæves de didaktiske overvejelser, som et aspekt der er vigtigt at være opmærksom på i designet af disse forskellige former for læringsmiljøer. Endvidere omhandler en af artiklerne en trend indenfor online Iæringsmiljøer; nemlig Massive Open Online Courses (MOOCs), hvor forfatterne stiller spørgsmål ved den dialogbaserede pædagogik i den tilrettelæggelse af læring. Den sidste artikel tager fat på emnet omkring e-materialer i online læringsmiljøer og den rolle som bibliotekerne kunne have i forhold til tilgængeligheden af online materialer.

* "Læringsrum og vidensudvikling i professionsuddannelser" af Nyvang og Dau

Artiklen stiller egentlig spørgsmålet: Hvornår opstår læringsrum? Gennem artiklen redegøre forfatterne for, hvornår der er en opfattelse af et læringsrum i konteksten af forskellige former for undervisningsrum (rammerne for læring). De to cases der danner grundlaget for analysen er indenfor radiograf- og lærer-uddannelserne på professionshøjskolerne (UCN). Den didaktiske tilgang i de to cases er at læring sker i sociale konstellationer; læring sker i en social praksis. I artiklen konkluderer forfatterne at forskellige typer af rum så som sociale, mentale og fysiske rum understøtter forskellige betingelser for læring, og disse betingelser er $i$ spil ved ibrugtagning af nye uddannelses- og læringsrum.

* "Synkrone online læringsmiljøer - didaktisk design for synkron undervisning understøttet af digitale teknologier" af Christensen, Gynther og Jørnø

Artiklen bevæger sig indenfor et lærings fænomen; nemlig brug af synkrone online læringsmiljøer, hvilket ikke er særlig udbredt endnu i Danmark. I artiklen opstiller forfatterne et design framework der understøttet didaktiske overvejelser og design af læring i synkrone online læringsmiljøer. I artiklen arbejdes med tre design dimensioner for design frameworket: simulering; remediering og innovativ transformation af tilstedeværelsesundervisning. Konkret tager artiklen fat $i$ brugen af Adobe Connect som det online læringsmiljø hvor igennem undervisningen medieres. Gennem analysen konkretiseres de design didaktiske overvejelser og principper, der ligger til 
grund for det præsenterede design framework.

* "MOOCs - perspektiver for UC-sektoren i Danmark" af Kjærgaard, Kjeldsen, Jelsbak og Bendsen

Artiklen har fokus på MOOCs og giver en klar gennemgang af de forskellige typer af MOOCs der er, samt disse betydning i en læringsmæssig kontekst fra et nordisk/skandinavisk perspektiv. Forskellige underviser kompetencer som kunne være i spil for at designe eller udvikle en MOOC præsenteres $i$ artiklen, og der stilles spørgsmålstegn ved netop den dialogbaserede og medinddragende pædagogiske tradition som er gældende for bl.a. UC'er men også andre uddannelsesinstitutioner $i$ Norden. Forfatterne samler afslutningsvis op ved at opstille nogle af de overvejelser som er væsentlige at gøre som uddannelsesinstitution inden man giver sig til at udvikle MOOCs i organisationen. Dog har de en væsentlig pointe $i$ at hvis en underviser udvikler læringsobjekter til MOOCs, så vil disse også kunne anvendes i en "Flipped Classroom" pædagogisk kontekst.

* "Kan forskningsbibliotekernes e-materialer være e-læringsmaterialer tilgængeliggørelse og formidling i elektroniske læreomgivelser" af Engerer En artikel omkring hvordan bibliotekernes rolle omkring e-materialer udvikler sig og kan sættes i sammenhæng med fremtidens virtuelle læringsmiljøer på bl.a. universitetet eller lign.

Dette kan de bl.a. ved at skabe større synlighed mellem VLE og ematerialerne således studerende via deres VLE har direkte adgang til søgninger etc. Samt ved at understøtte den formidling der bør følge med, da bibliotekerne har gode forudsætninger for at indgå i et læringsmæssigt samarbejde $i$ undervisningsregi lige så vel som i forskningsregi.

Samlingen af artikler i dette temanummer af LOM illustrerer, at der rundt om i organisationer er mange forskellige interessante initiativer i gang, i forhold til at se på hvordan undervisning og læring bl.a. teknologisk kan understøttes og være medvirkende til at skabe nye, spændende og alternative undervisningsmiljøer og metoder.

\section{God fornøjelse med den videre læsning af artiklerne}

mange hilsner

Redaktørerne 